\title{
WHEN THE TEENS NARRATE THE SELVES IN INDONESIAN LITERATURE: GENDER, SUBJECT, AND POWER
}

\author{
Wening Udasmoro \\ Department of Language and Literature, Faculty of Cultural Sciences, Universitas Gadjah Mada \\ Jln. Nusantara 1 Bulaksumur, Yogyakarta 55281, Indonesia \\ udasmoro@ugm.ac.id
}

Received: $01^{\text {st }}$ August 2017/ Revised: $24^{\text {th }}$ August 2017/ Accepted: $30^{\text {th }}$ August 2017

How to Cite: Udasmoro, W. (2018). When the teens narrate the selves in indonesian literature:

Gender, subject and power. Lingua Cultura, 12(1), 53-60.

https://doi.org/10.21512/lc.v12i1.1961

\begin{abstract}
The subjects that participated in the production of meaning in the literature included authors, publishers, and illustrators. The aim of this article was to investigate the role and the exercise of the power of these different subjects in trying to construct teenager identities through teen's literature in different eras of Indonesia. Different teenager literature was analyzed since The New Order to the Reformasi Era of Indonesian political rule. This research used the Critical Discourse Analysis method, which examined all social and cultural products as discourse. Discourse in this context was the construction that contained within it components that require attention. The analysis shows that there is an environment of gender, middle-and upperclass production, consumption, and the reproduction of narration by those different subjects. All of them compete because they have different agendas. However, they also negotiate and work collaboratively through their own narrations, because they all have the same objective of acquiring financial benefit.
\end{abstract}

Keywords: teen naration, teen identities, teen literatures

\section{INTRODUCTION}

Literature is not a neutral product regarding the balance of power, both in its production and consumption by readers (Johnson, 2016). When Roland Barthes argues that the author is dead, he means that the text written by the author is not a closed one, but it is open to diverse interpretations because nobody knows the author's exact intention when writing a story (Barthes, 2006). Barthes' argument is also compatible with that of Wolfgang Iser, who emphasizes the importance of readers in the interpretation of the text. Meaning is not just the product of the author; it is produced by readers based on their storage of knowledge obtained from reading literary works (Iser, 1978). These two arguments must be understood in relation to the individual who acts as the subject in the production of meaning of literary works.

These arguments can also be used to understand the power of subject in relation to the production of meaning in literary works. Michel Foucault has argued that the discussion of the subject is always related to the concept of power (Foucault, 1980). Power, according to Foucault, is not fixed to a subject rather; who is the subject depends on who exercises power. In this contemporary world, where literature is also connected to the power of financial capital or the power to buy literary products, the relation among different subjects is also more complex.
Literature is not only a work of art to be appreciated by literary critics, but it is also a part of the media industry. In that context, it is crucial to discuss the power of the media industry in order to understand the relation of power between the production of literature by authors, the consumption of literature by the readers, and the reproduction of literature by the media industry (Talbot, 2007). For example, in the two previous decades in Indonesia, the dominant power in literature could be seen from a large space occupied by the production of literature for adults by the adults (Nurgiyantoro, 2004). This is based on the media industry's assumption that more financial capital could be gained from the adult type of literary production. Teenagers and children have less narrative space to construct their own identities (Steiner \& Steiner, 2009). However, when teens and children are narrated, it is adults who narrate their narration, and as such, the construction of teen's narration is dominated by the views of the adults (Garner, 1999). The adults become the most important subject in the construction of teens' identity during that period.

Recently, in Indonesian, there is the teenager's literature that is called teenlit. However, teenagers have attempted to create their own narrations despite the fact that the stories consumed by most teenagers are those narrated by adults (Sarumpaet, 2010). Some teenagers write stories to compete with adults in the industry of literature. They are motivated to participate in the construction of their own 
identity (Meyer, 2013) and also their own desires (Meyer, 2013) and also their own desires (Mackey, 2011). The media industry is aware that the teens are also a promising market (Cohler \& Hammack, 2007). The production of teen literature has thus developed very rapidly after the Reformasi movement that begins in 1998. The change of political and social regime, from an authoritarian to a democratic one, does enable free market and capitalism to enter Indonesian public life (Sen \& Hill, 2011), which provide the impetus for more subjects to exercised their power in the construction of teenager narration and identity (Nurgiyantoro \& Efendi, 2017).

The objective of this article is to investigate how the different subjects are playing their roles in trying to construct teen's identities through teenage literature. What are narrations of teenage from the point of view of gender and social class mainly developed? What are teenage ideologies introduced through different subject's narrations? Ultimately, the focus of this article is to glean the emerging constructed identity of teenage, especially from the gender and social class perspective by different subjects in the teens' identity construction process in Indonesia literature.

\section{METHODS}

This research uses the Critical Discourse Analysis method, which examines all social and cultural products as discourse (Fairclough, 2002). Discourse, in this context, is a construction that contains within it components that require attention (Van Dijk, 2006).

Several levels require attention. The first level that requires attention is language (Fairclough, 2003). Language is important because it contributes to the construction of discourse (Fairclough, 2003). In works of teen literature, the language used by teenagers is an important point of attention. Language, in this case, is represented in the text (Maingueneau, 2006b). This can be understood as oral and written language (Fairclough, 2014). However, in the poststructuralist approach, the text is not limited to simply oral and written language. Images are text as well (Van Leeuwen, 2008). As such, in this article images are important and used as units of analysis. The data corpus originates from sentences, paragraphs, discussions, as well as the visual and pictorial units and symbols that are displayed.

The second component that requires attention is that every discourse has a reference, the discursive level (Fairclough, 2014). This discursive level is a mindset found within every text. Discourse at this level emerges as a result of repeated repetition that occurs in every individual experience and ultimately develops into belief (Butler, 2013). Continuous repetition transforms the conscious into the unconscious (Butler, 2011). For example, why does the color pink often emerge in the illustrations in teen literature? This is because of the consumptive patterns in the text, in which the color pink is dominantly consumed by a certain gender.

The third component is the practices chosen by individuals as a result of the complexities of language and reference (Fairclough, 2014). Authors and publishers, for example, select specific practices in determining narrations or symbols used in literary works. A social effect emerges, one related to the text produced by the subject and to the reference. However, there is not always coherence between the text, reference, and social practice. There is a thread, one that is not always synchronically connected, because within each subject there are always references to different origins. These references are multi-dimensional, as subjects have different perspectives on the different references. Likewise, on the subject, there are various voices that differ because of the varied references accumulated within the subject's cognitive space (Maingueneau, 2005).

\section{RESULTS AND DISCUSSIONS}

The teen lit formally emerges in Indonesia in the 1970 s and is promoted especially through the novels of Eddy D. Iskandar, an adult male novelist who has his male perspective in his writings. His novels, such as Puspa Indah Taman Hati (Beautiful Flower, Garden of the Heart) or Gita Cinta dari SMA (Song of Love from High School) are among the first novels produced that target the teenage readers and can be seen as an attempt to reach an underserviced market. The coming of teen lit does fulfill the teens' interest in reading novels that are accorded with their experiences as teenagers. The most frequent theme in such teen lit is romance between teenagers. In these love stories, the question of difference in regard to social background becomes one of the most common issues raised by the authors. The teens in these stories deal with the emotions of happiness and sadness of their daily relations. Figure 1 shows some front covers of novels for teenagers in the 1970s.
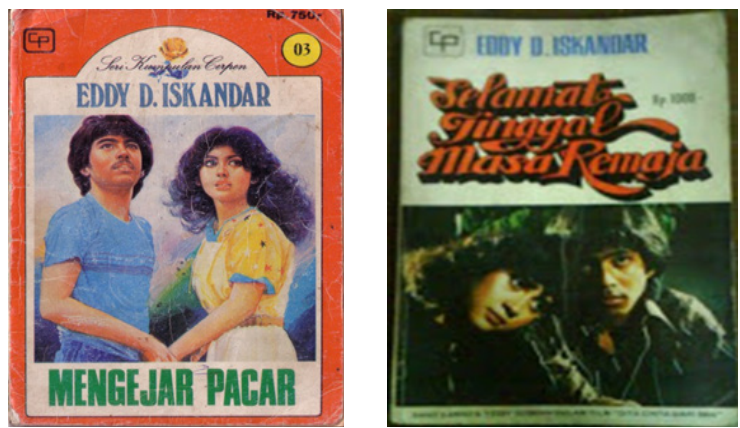

Figure 1 Indonesian Teenager Novels in the 1970's (Source: www.amartpura.com and www.pricearea.com)

The subject-object relation in these works of teen literature is based on the author's intent to create a new way to conceptualize literature; literature is not only for adults but also for teens. However, the author (Iskandar) is not alone in trying to narrate teens. Indeed, Eddy D. Iskandar writes teen lit because of the high demand from the film industry, and eventually teen lit becomes the first producer of ideas for the development of film industry in Indonesia. A later edition of Selamat Tinggal Masa Lalu (So Long the Past) that is shown in Figure 1 uses photographs of the actor and actress from the movie on the covers of that work. The novel's author and publisher combine with the film industry, act as subjects, work together, and use different powers to create a narration of teens. The teens' identity is constructed based on the symbiotic mutualism of different interests. Ultimately, most of Eddy D. Iskandar's novels are adapted to film, which only focused on common everyday teens' experiences.

In the early $1980 \mathrm{~s}$, the teen literature begins disappearing as its readers become more interested in adult novels, particularly with the works of Titi Said Sadikun 
and La Rose. However, the teen lit re-surfaces in 1986 with the popular novel with the title Lupus, written by Hilman Hariwijaya. Since Hilman Hariwijaya writes the novel when he is 22 years old, the narration of teenagers continues to be created through the narration of adults. The novel Lupus is a narration story of a young boy, named Lupus, and focus on his daily life experience (Safrina, 2011). Like the earlier works of teen lit, the relation between boys and girls are dominant in the novel. However, there is a difference from the previous ones; while Eddy D. Iskandar attempts to write his novels based on teen's common experiences, Hilman Hariwijaya acts as a subject in the stories in an attempt to create a new identity for teens by using his own profile.

Lupus' identity is the representation of the author's identity, or more specifically, the author creates Lupus as his own portrait. In social practice, this novel inspires young boys to follow the fashion trends that are promoted by Lupus in the novel (Hilman \& Boim, 2013). The fashion trends include one having long hair, chews gum, and folded shirt sleeves, which become a style, whereby teens are attracted to follow in that period. These representations are becoming the discourse because they are living in the teens' daily life in everyday activities. Lupus also inspires the film industry, and again the strong subject of the author is integrated with the literature and film industries in constructing the identity of the young people. The young people (youths) are objects and commodities in the social practice. They are also the followers of trends that are created by the authors and industries, including the chewing gum industry. Hence, Figure 2 shows a picture of the author of Lupus, compares with the front cover of one of his novels (Boys Don't Cry).
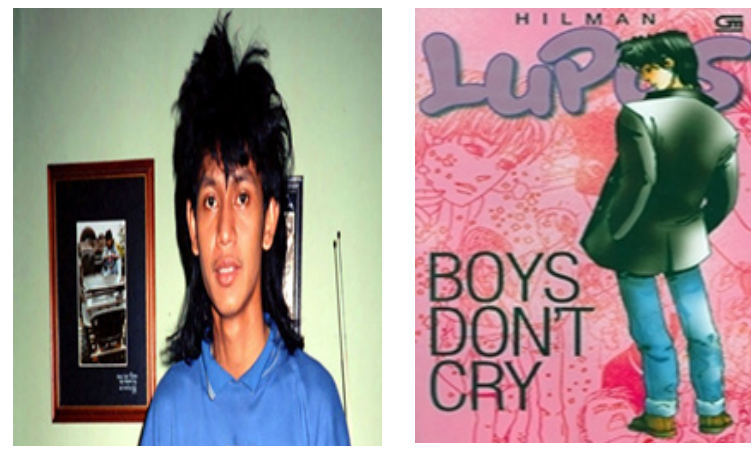

Figure 2 Indonesian Teenage Novel in the 1980's (Source: www.tempo.co.id and www.downloadebookbuku.blogspot.com)

The popularity of teen lit declines again by the end of the 1980s. After Lupus, there are no further works of teen lit releases as novels. Instead, most literature for teens is published in magazines targeted for the whole population. The writers take advantage of the increased interest for teenage magazines in the media industry (which included publications such as Aneka and Gadis for girls and Hai for boys) to publish their short stories or serials. The motivation to write stories in the teenage magazines continues until the end of the 1990s. The subjects in this period are the media industry. Teens, meanwhile, begin to act as readers with their own interpretations and it is then that they start to write their own narrations and publish in teenager magazines.

The Reformasi era in Indonesia in 1998 creates more space different social actors (Aspinall, 2015), including authors to express their ideas and opinions. This change of political regime also creates more possibilities for the media industry (O'Rourke, 2002). In particular, the media industry attracts not only adult authors to write novels but also teenagers themselves who are interested in writing their own stories.

There are at least three types of the teen lit in the Reformasi era (Udasmoro, 2013). The first type is teen lit that is written by adults but narrates stories about teenagers (Nurgiyantoro, 2004). These stories are related to many issues but usually convey a message about friendship, nationalism, etc. This type of literature has a broader audience and can be read by both teens and adults. Andrea Hirata's Laskar Pelangi (Hirata, 2005) and the A. Fuadi's Negeri 5 Menara (Fuadi, 2002) are some examples of such type of teens' narration. This first type of novel still attracts the film industry. Both of the novel examples have been adapted to film and watched by the diverse audience.

The second type is the teen lit created by authors who are no longer teenagers, but the young youth. The authors in this category include Raditya Dika, Endik Kuswoyo, and Fitri Rakhmawati. There are even some publishers that emphasize the words "teen lit" on the covers of novels. With this type of teen lit, both male and female authors compete to write stories about teenagers.

The third type is the teen lit written by teenagers themselves (Hunt, 2005). They create their own narration to express their identity as the teenager. The largest publisher of this type of teen lit is Dar Mizan, which publishes several series of teen lit written by the teenagers. One such series is Kecil-Kecil Punya Karya (Small Authors who Have Stories). The teens that write the stories in this series are mostly girls, and as a result, the series.

As seen from the previous discussion, the discourse of teenagers in literature from the Reformasi era is more diverse than that of the previous New Order era. In term of style, when seeing from discourse analysis perspective (Van Dijk, 2006), the authors of the first type of literature remain idealistic in their writings. The diction and sentences are formal, and the authors aim to perpetuate literary writing that conveys a message consisting of the moral value for the teens, even though in Indonesian such works are not considered as having an aesthetic value, as serious literature. Nonetheless, the writers of this type of literature are considered popular authors.

In contrast, the authors of the other two types of teen lit have a similar perspective when narrating teens, and their contents have some similarities. From these different approaches, different authors act as subjects who produce knowledge that contributes to the production of culture (Bourdieu, 1994) of writing in Indonesian teen lit. The discussion primarily focuses on those two later types of literature described.

Symbols are placed as sharing of meanings in discourse analysis. In this context, many symbols, such as language are used in teen lit to narrate teens' identities (Pahl $\&$ Way, 2006). The gender construction can be seen from the symbols used in the teenager literature that appear as discourses spread in the society used in everyday life (Moje \& Luke, 2009). A combination of social and individual construction is negotiated in order to construct the identity of the teens (James, 2008). The color pink, for instance, is used to explain the identity of young girls. It is not an arbitrary choice, but a socially constructed one that is not only used in the front covers of Indonesian teen lit, but the stories also emphasize the usage of this color. Figure 3 presents some front covers of recent teen lit with pink color. 

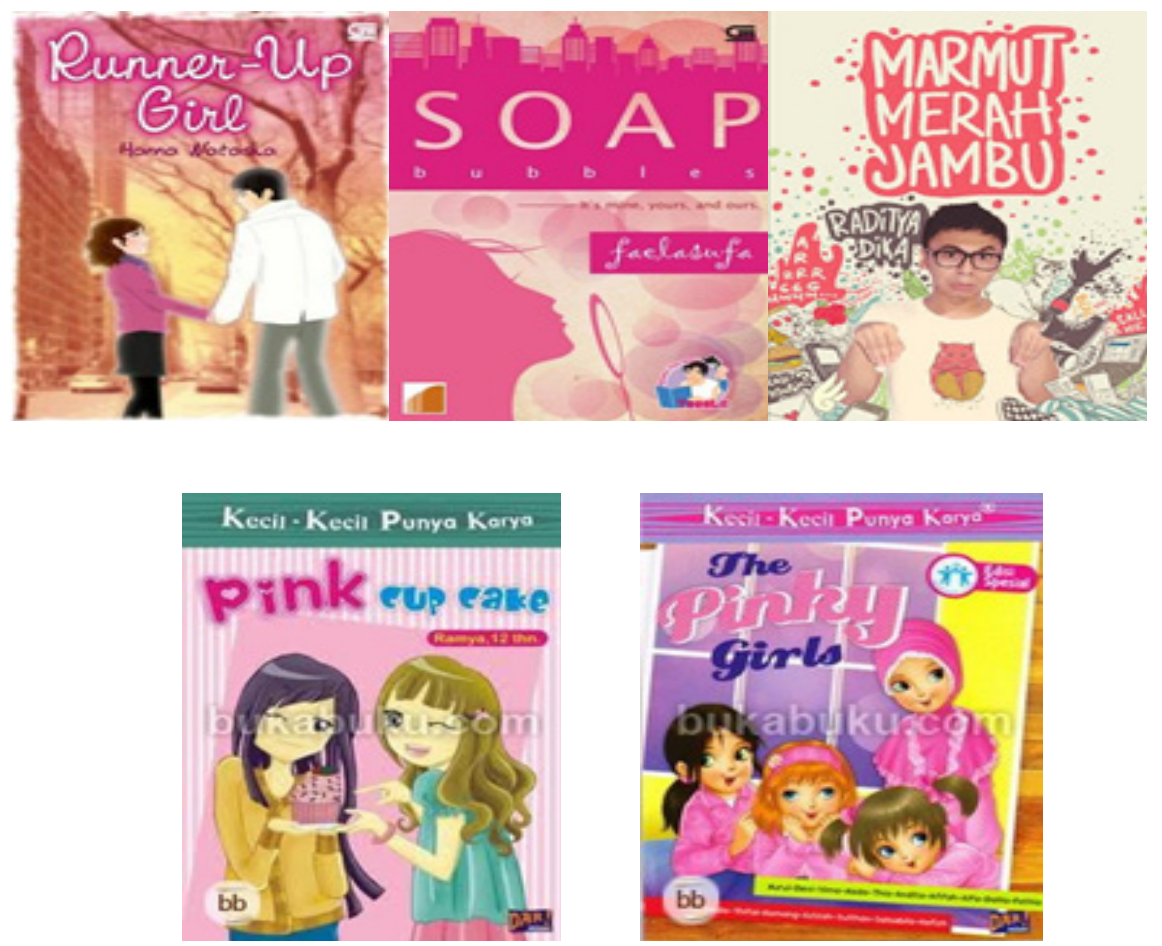

Figure 3 The Indonesian Teenage Pink Color Novels (Source: www.bukabuku.com)

Five pictures in Figure 3 and the three on the left side have the covers of teen lit written by young writers who are no longer teens, whereas the two on the right side are from the series Kecil-Kecil Punya Karya, written by the teenagers. All of these novels have pink color on their front covers. The titles of the three books on the right use illustrations related to the pink color. Marmut Merah Jambu (Pink Marmot) is written by Raditya Dika (male author), one of the Indonesian best-known young writer that talks about a girl with whom a boy is falling in love. Although Raditya Dika is a male, he uses the color pink to represent a girl. The two other novels that use the word "pink" as part of the title. The books talk about the things that girls like, such as cupcakes, and have the pink color. The title Pinky Girls makes the association between girls and the color pink more explicit and relational.

The novels use pink color in their front cover because, in the construction of identity, the relationship between the constructed self and the other depends on how the process of construction takes place. As such, the choice of pink color is chosen to distinguish such books from other colors, which are usually used by different categories of gender and age. The symbolism, in which girls are related to the pink color, is well-established, especially in the western tradition. The influence of the western tradition of color representing gender is transferred to Indonesians through the media, including television shows, advertisements, etc.

In the context of Kecil-Kecil Punya Karya, the influence of television is conveyed through the films that are produced and consumed by children and teens. The pink color is produced in the culture of Barbie, a figure of a young girl that is created as a perfect creature. In the culture of Barbie, the hero of the story, named Barbie, is associated with the pink color although it has been utilized historically in western tradition to differentiate with boys, who are given the color of blue is emphasized in the Barbie culture (Udasmoro, 2012).
The culture of Barbie is then reproduced in teen lit to symbolize youth. Young girls are then given a distinct symbol (Soelistyarini, 2013). The pink color is used to cement the social construction that girls are related to pink, whereas boys are represented by blue color. Though such color construction is a social one, the teens are the ones who also participate actively in constructing themselves in order to distinguish themselves from others in the society. The separation between different social groups reinforces the border between two genders in the everyday discourses (Maingueneau, 2006a).

Because the colors representation of the two sexes is repeated daily, this constructed reality becomes a sex identity, where young people believe that teenagers, especially girls must be associated with pink color. Different subjects, such as the authors (including a male author) and the publishers are incorporated into this view to reproduce this reality. Although some teen writers try to be distinct from others in order to create a specific self by using a different color, the popular perception of the majority towards pink color as girl's identity remains robust and the favorite choice.

The stories in teen lit, especially in the Kecil-Kecil Punya Karya series, are dominated by western narration and integrated with the practice of religion, particularly Islam. Related to gender, the symbols used are particularly addressed to the girls. The symbols of Islam used, for instance, is the fashion code, such as the wearing of the veil (hijab), and the usage of language related to the girl's activities. These Islamic symbols are used together with English in the stories. In one story, for instance, the titles of the chapters are mostly in English. The front covers of Kecil-Kecil Punya Karya books in Figure 4 shows how symbols of Islam and the west are used at the same time and in the same space in the stories. 

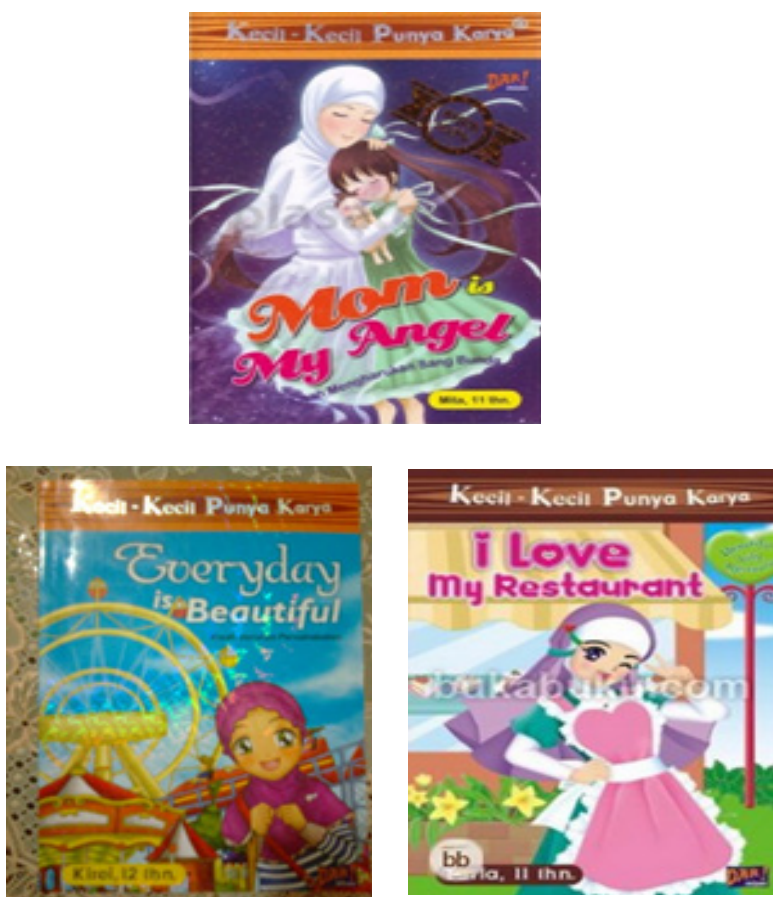

Figure 4 Kecil-Kecil Punya Karya Books (Source: www.bukabuku.com)

Islam and western symbols are addressed for the girls that are often considered as two different competing poles in social and political practice. It is used at the same time in displaying a story because it cannot be separated from the cooperation of different subjects in the industry of teen lit. Dar Mizan, as the publisher, is a subject that contributes to this construction of narration, while the girls are used to construct this narration. Dar Mizan publisher holds an Islamic ideology with the ideological message, which wants to convey and on the other hand, is a way to attract the target market. Indonesia is the largest Muslim country in the world, and with the rapid economic growth after the Reformasi movement in 1998, the rise of the middle and upper class has been significant (Ansori, 2009). Targeting the Muslim in middle and upper-class readers is the publisher's marketing strategy for financial gain. Indeed, Kecil-Kecil Punya Karya books are quite expensive for the lower-class consumers, and as such, the series' target audience of middle and upperclass children is readily evident.

The intervention of the publisher is also shown in the stories. Most authors do not discuss the fashion code used by the heroes in the story. However, Dar Mizan regularly creates novel covers that emphasize the Islamic fashion code, especially for the girls. The authors are indeed subjects because they are the ones who produce meaning through the language in their stories. However, they cannot interfere with the power of the publisher, because they have a financial interest to publish their novel(s) with this well-regarded and established the company. In business, the fact remains that to publish a story is not an easy task because of the strong competition among authors in the teen lit industry, which creates a power relation, where the publisher has more power, particularly in deciding the front cover of a novel.

The Islamic symbols used in the novels are becoming more complicated and diverse because they combine western with modern symbols. With the usage of English in most of the titles of teen lit together with the significant occurrence of symbols of modernity such as computers, gadgets, and other forms of information technology, it is a strategy for teen girls to show and promote their identity.

There are three possible explanations for this situation and in particular. It relates to the usage of English language in most of the stories. First, most of the authors of the stories in Kecil-Kecil Punya Karya are Muslims girls, and they come from certain social class. The authors as producers, and readers as consumers, both represent middle and upperclass teens. The authors choose symbols that represent their gender and social class. The English language is used to explain the social class and to whom the authors want to communicate with. In Indonesian context, the identity of middle and upper-class teen girls is constructed closely with the usage of English. Hence, the distinction of social class is marked by the use of English language (Oyvind, 2005).

Second, the basis for the use of English language is found in the social practice whereby the parents are motivated to improve their children's social capital by sending them to the schools, where English is a primary language of instruction or a heavily-emphasized subject. This situation has also been influenced by the State's regulation of the national curriculum of 2006 (Pusat Bahasa Universitas Trisakti, 2013), which emphasize the importance of the usage of English beginning in primary school. Numerous schools that use English as a primary language of instruction have been established since then. Although the recent national curriculum of 2013 is the revised version of 2006 one that reduces English to a secondary subject in primary schools, many private schools with English-based curriculums continues to teach English as the primary subject. Moreover, there are some schools known as English full-day classes and use English as their only language of instruction.

The teens that write the Kecil-Kecil Punya Karya are a product of English schools that described above. They use the English language because their social environment opens a space for them to use it. The middle and upperclasses have benefit to a greater extent from such English learning environment. The usage of English mixes with symbols of Islam is a way to convey self-identity in the teens' construction of identity. This construction of identity shows these teens' authors distinction from others.

Third, the teen girls that write such stories are often the ones that have been traveled abroad. Some of these teenagers have lived abroad with their parents and are educated outside of Indonesia. They write stories about their experiences while living abroad. Retelling their experiences in other countries is important because it links to the psychology of distinction, which is crucial in the analysis of identity construction in teen lit. The ability to travel abroad for teens and Indonesians, in general, represent someone of high status. People are considered rich and cultivated if they can travel to other countries including these teenage authors. By narrating one's experience in another country, the author can boast of things that other teenagers such as those in the lower class cannot do. The lower class teens are subordinated because of their social class. The subordination of the lower class people can be traced in many other societies as well that become the pattern in the social relation (Peterson, 1994).

Bourdieu has argued that financial capital is not the only thing which is important in human relations but symbolic capital as well (Bourdieu, 1984), an argument which Indonesian teen literature supports. The usage of Islamic and the western symbols in the novels underscore 
high financial and symbolic capital in the context of Indonesian teenager literature. Both forms of capital are used to place subjects in a relation of power with other subjects in a gestalt of teen lit (Yunita \& Udasmoro, 2015).

The use of western symbols is strengthened through the use of modern technology. In most of the teen lit surveyed, the authors write about the use of modern technology, including mobile phones, gadgets, and computers. In a story in Figure 5 that is composed of nine chapters, there is an image that illustrates the hero's activity in the story. Of these nine chapters, seven of them use information technology as part of the illustration.
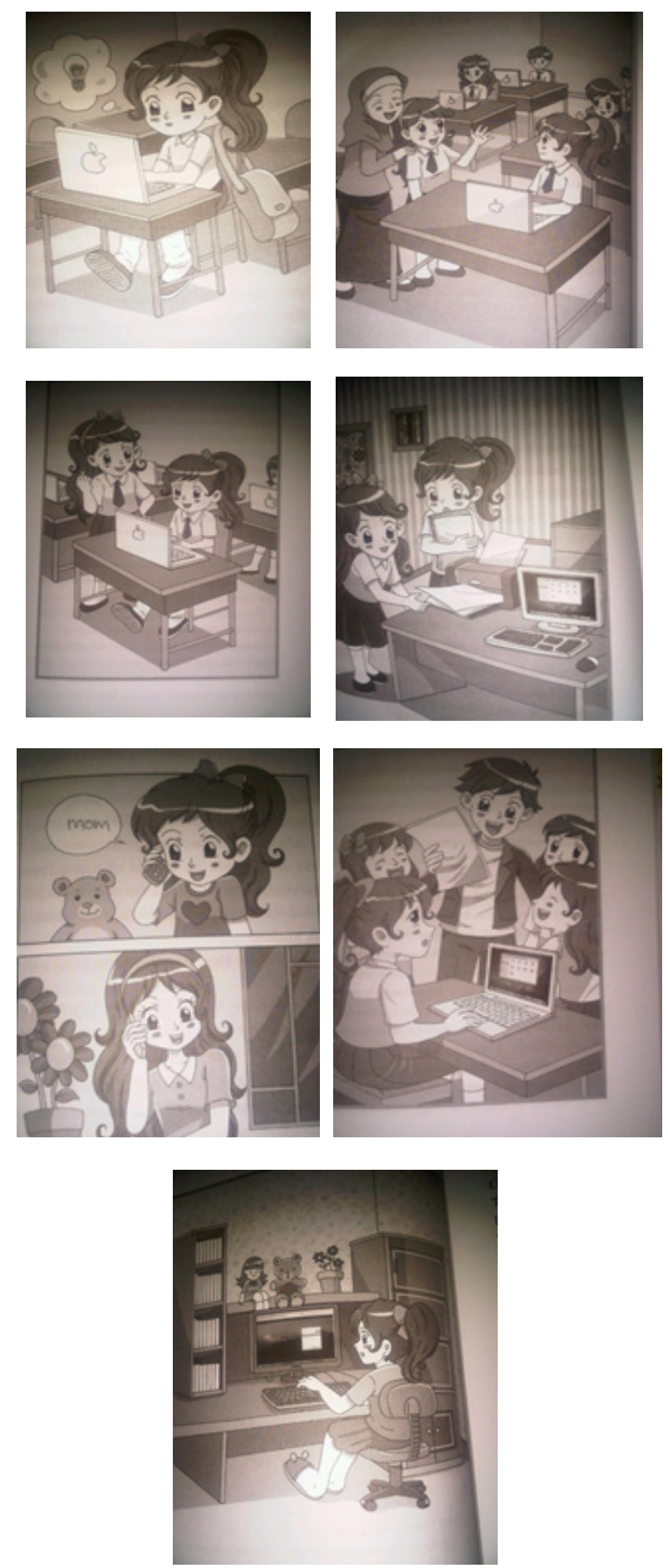

Figure 5 Indonesian Teenage Novels with Modern Technology
One aspect of Figure 5 that uses of technology illustrations shows the prominent use of information technology, which also represents the upper-class teenagers (Livingstone, 2008). This particular novel tells of an English Writing Club that is joined by the teen girl, or in more general terms, of an upper-class family which sends their child to a social activity for upper-class people. This group of students is provided with an expensive brand laptop, which is Apple Macintosh. The illustrator has strengthened the symbolism of social class by drawing a top brandname laptop. All of the subjects involved in the production of this series, including the author, the illustrator, and the publisher have the same perception in the production of meaning. They concur to use teen lit to construct a middle and upper-class social environment through messages and meanings that represented the class of people. The objective is to create distinction, which in this case defines the high status of the teens in the society. This confirms Bourdieu's argument that the high status is a transformation of capital from the financial one into a symbolic one (Bourdieu, 1984).

The world of consumerism is also celebrated by teens in creating one's own identity. The teenage readers are told that it is not a taboo to discuss money, despite their age. This money discourse is reinforced in many different ways. In the contemporary world, in which literature has become a product sold in mass market, understanding this moneymaking attitude can be seen not only from the content of the novel but also from some other components of the novels. These include the illustrations, the discourse in the acknowledgments, and others that are covered in the novels. In the acknowledgments for a novel titled Andien's Stories (Rania, 2013), for instance, the author (a teen girl) writes several sentences in which she repeatedly shows a moneymaking attitude.

I hope a lot of people buy my books.

To all of my friends, please keep on buying my books, although I cannot give you a discount.

Thanks to for all of the readers who have spent their money to buy my book.

Another example is the narration of earning money despite the author, and the hero of the story is very young. Earning money is not a tradition for upper-class teens in Indonesia, which is different from the western practice and tradition; it is only the lower-class Indonesian teens that have to earn money in social practice in order to make a living amongst the poor. The quote shows the new money making culture, as narrated in particular Indonesian teen lit.

Although still small, Marshya already works. She works as a cook at Yummy Frenzy Restaurant in New Zealand. Her salary is quite high. Marshya is very happy to work and stay in that country.

The money-making culture propagated by the author in the story is actually an over-dramatization. It is impossible for a girl aged 12 years old or younger to be working in a restaurant in New Zealand. The laws in New Zealand prohibit under-age employment and child abuse. However, such narration tries to capture the idea in the western tradition, whereby such work does not belong only to lower class but to any other class. Young people from middle and upper-class can also work in any restaurant to 
earn money. However, the perception that a small girl can also make money is used to dramatically show how the culture of the west has been applied by the author, despite the misinterpretation in the real application of such practice. The most important aspect exhibited by the author is how the young girl has adopted western culture and habits, such as earning a decent salary.

In order to differentiate herself from poor Indonesian teens, who must earn money in the actual social practice, the author has created a different situation. The girl in the story does not make her money in Indonesia, but in a rich, modern, and foreign country, New Zealand. Despite the similarities, there is still a vacuum, where she can be differentiated in that context. Hence, both poor and rich teens make money, but for the poor, earning a salary is a struggle; whereas for the rich, it is a source of status, pride, and amusement.

Indonesian teens are also familiar with the modern lifestyle, where they go for shopping, have holidays, travel to another country, and engage in other activities of the upper-class. These activities are narrated in the novel series. The novels in Figure 6 with titles Shopaholic, France I'm Coming, and My Wonderful Holiday, show how the culture of consumption and its resulting lifestyle have become the teens' goal in Indonesian literature.
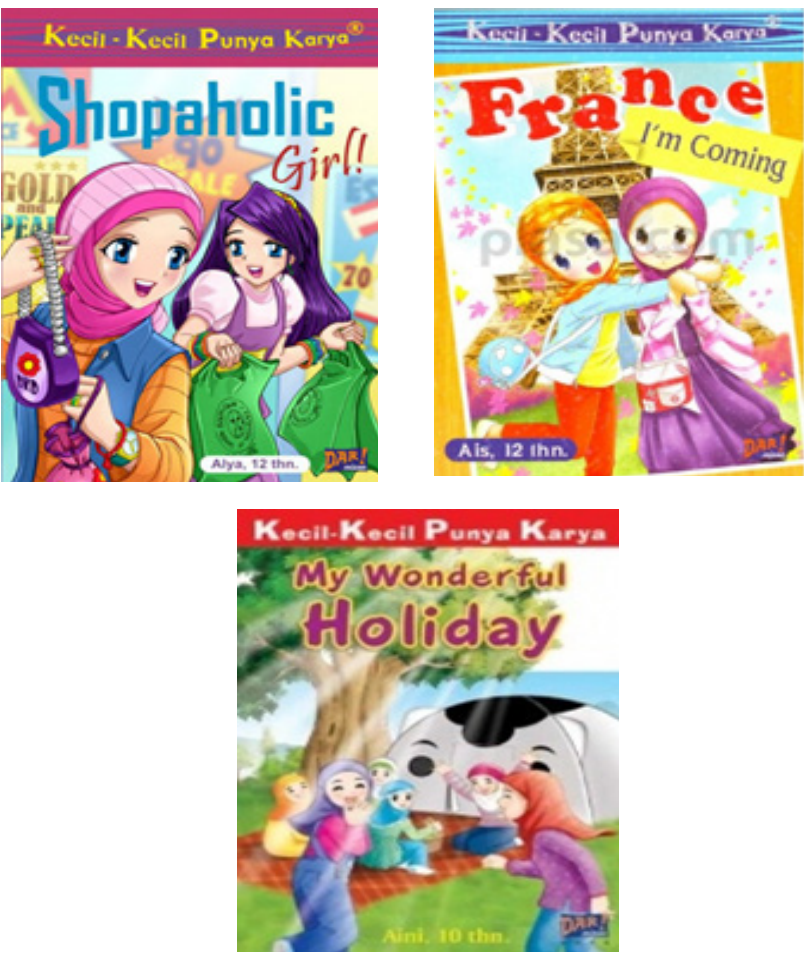

Figure 6 Indonesian Teenage Novels of Modern Lifestyle (www.bukabuku.com)

The book covers in Figure 6 show that in stories related to shopping; the ones who shop are not only the antagonist actors. This narration is different from the tradition of the teen stories in an Indonesian context. To live simply has long been the discourse of the Indonesian State in the past. In those years, the emphasis on simple living has been part of the Indonesian education system. In most of the stories for teenagers broadcast on television during former President Suharto's era of political rules, such as in the series Aku Cinta Indonesia (I Love Indonesia) and Keluarga Cemara (Cemara Family), the simplicity of life is always emphasized. The protagonists are always the simple girls, while the antagonists are the rich and greedy girls. This tradition is rapidly changing. Shopping is no longer seen as something that young girls should avoid. Society is consumptive especially when the middle and upper-class is the reference point.

Travelling and having holidays are also part of how the identity construction is frequently narrated in teen lit. These activities have become common in middle and upperclass Indonesian families. These upper-class activities are symbols of taste and one having a solid financial standing. Although children can travel and have holidays because every school in Indonesia organizes at least one trip a year for a school excursion, having holidays abroad are exclusively for financially well-off middle-and-upper class privileged children.

\section{CONCLUSIONS}

The teenager literature is targeted at a certain gender and social class and is produced by authors, especially the girls from the same social class. There is an environment of the gender of middle and upper-class production, consumption, and the reproduction of narration by different subjects. All subjects are competing because they have different agendas.

There is a relation of power between the authors, publishers, illustrators, and many other different subjects who try to promote their agenda. However, apart from competing among each other, they also negotiate and collaborate through their narrations because they have a similar objective of achieving financial benefit. The girls become on the one side subjects who narrate but on the same time objects narrated. It is the girls who are targetted because of the interest of the market who consume the product of the literature.

Literature has become a space to construct teen girls identities, in which different ideologies and meanings are produced. The production of meaning in this construction discusses in this article; however, it has never been neutral. There is always a question of social class, gender, and ideology contested in the narration. The subject that own capital always has more power to dominate the narration. However, authors can also push forward their own narration as they have another form of capital as story tellers. The issue is that the different subjects are positioned to only narrate about their class. The narration of this social class is because of the industry of literature (publishers) who want to get benefit from this social class. There are always other narrations that are excluded and marginalized in these stories, which include other religions, social class, and gender.

Regarding religion, other religions outside Islam are not represented in the narration. The position of the publishers with Islamic ideological background explain this situation. For class, the lower class has never become a subject of narration since the target of this book production is for the middle-high class consumers. For gender, in works published in Reformasi era such as Kecil-Kecil Punya Karya, boys are under-represented in the narration. The distinctions of gender, social class, and religion in the teenager's literature here show that the marginalization is already constructed since the teens' age. It shows that the narration of teenagers is addressed to certain social categories. 


\section{REFERENCES}

Ansori, M. H. (2009). Indonesian middle class. Exploration, 9, 87-97.

Aspinall, E. (2015). The new nationalism in Indonesia. Asia and the Pacific Studies Policy, 3(1), 72-82.

Barthes, R. (2006). The death of the author: Critical Theory since 1965 (H. Adams \& L. Searle, Eds.). New York: Wadsworth.

Bourdieu, P. (1984). Distinction: social critics of the judgement of taste. New York: Routledge.

Bourdieu, P. (1994). The field of cultural production: essays on Art and Literature (R. Johnson, Eds.). New York: Columbia University Press.

Butler, J. (2011). Gender trouble: feminism and the subversion of identity. New York: Routledge.

Butler, J. (2013). Excitable speech: a politics of the performative. New York: Routledge.

Cohler, B. J., \& Hammack, P. L. (2007). The psychological world of the gay teenager: social change, narrative, and normality. Journal of Youth and Adolescent, 36, 47-59.

Fairclough, N. (2002). Language in new capitalism. Discourse \& Society, 13(2), 163-166.

Fairclough, N. (2003). Political correctness: the politics of culture and language. Discourse \& Society, 14(1), $17-28$.

Fairclough, N. (2014). Language and power ( $3^{\text {rd }}$ ed.). London: Longman.

Foucault, M. (1980). Power/Knowledge: selected interviews and other writings, 1972-1977 (C. Gordon, Ed.). London: Pantheon Books.

Fuadi, A. (2002). Negeri 5 Menara. Jakarta: Gramedia Pustaka Utama.

Garner, A. (1999). Negotiating our position in culture: popular adolescent fiction and the self-constructions of women. Women's Studies Communication, 22(1), 85-111.

Hariwijaya, H., \& Boim. (2013). Lupus kecil klasik. Jakarta: Gramedia.

Hirata, A. (2005). Laskar pelangi. Jakarta: Benteng Pustaka.

Hunt, P. (2005). Understanding children's literature $\left(2^{\text {nd }}\right.$ ed.). London and New York: Routledge.

Iser, W. (1978). The act of reading. London: Routledge and Keagan Paul.

James, K. (2008). Death, gender, and sexuality in contemporary adolescent literature. London and New York: Routledge.

Johnson, L. (2016). The author is dead: A lacanian response to Barthes's Return-to-the-Author Paradox i. Texas Studies in Literature and Language, 58(1), $1-19$.

Livingstone, S. (2008). Engaging with media: a matter of literacy? Communication, Culture and Critique, $1(1), 51-62$.

Mackey, M. (2011). Narrative pleasure in young adult novels, films and video games: critical approaches to children literature. London: Palgrave Macmillan.

Maingueneau, D. (2005). L'Analyse du discours et ses frontieres. Marges Linguistiques, 9, 64-75.

Maingueneau, D. (2006a). L'Enjeux de l'Analyse du discours. ANADISS, 1, 11-29.
Maingueneau, D. (2006b). Textes/Discours et co(n)textes. Pratiques, 129, 40-42.

Meyer, V. (2013). A literary mirror: Balinese reflection on modernity and identity in the twentieth century by Nyoman Darma Putra. The Journal of Asian Studies, 72(3), 748-750.

Moje, E. B., \& Luke, A. (2009). Literacy and identity: examining the metaphors in history and contemporary research. Reading Research Quaterly, 44(4), 415437.

Nurgiyantoro, B. (2004). Sastra anak persoalan genre. Humaniora, 18(2), 107-122.

Nurgiyantoro, B., \& Efendi, A. (2017). Re-actualisation of puppet characters in modern Indonesian fictions of the $21^{\text {st }}$ century. 3L: Language, Linguistics, Literature Journal, 23, 141-153.

O'Rourke, K. (2002). Reformasi: the struggle for power in post Soeharto Indonesia. New South Wales: Allen \& Unwin.

Oyvind, I. (2005). The power of social capital: adapting Bourdieu to the study of public relations. Public Relations Review, 31(4), 492-496.

Pahl, K., \& Way, B. (2006). Longitudinal trajectories of ethnic identity among urban black and latino adolescent. Child Development, 77(5), 1403-1415.

Peterson, C. (1994). Narrative skill and social class. Canadian Journal of Education, 9(3), 251-269.

Pusat Bahasa Universitas Trisakti. (2013). Bahasa Inggris dalam kurikulum SD. Retrieved from http://www. pusatbahasa.trisakti.ac.id

Rania, N. A. (2013). Andien's stories. Bandung: Dar Mizan.

Safrina, R. (2011). Lupus remaja Jakarta yang berada di posisi antara: Analisis ssubjektivitas dan agensi remaja. Jakarta: Kiblat Buku Utama.

Sarumpaet, R. K. T. (2010). Pedoman penelitian sastra anak. Jakarta: Yayasan Pustaka Obor Indonesia.

Sen, K., \& Hill, D. (2011). Politics and the media in twentyfirst century Indonesia: decade of democracy. London: Routledge.

Soelistyarini, T. D. (2013). Representasi gender dalam cerita-cerita karya penulis anak Indonesia seri KKPK. Mozaik, 14(2), 182-197.

Steiner, S., \& Steiner, B. (2009). Bullies, gangs, and books for young adult. YALS: Young Adult Library Services, 7(4) 39-45.

Talbot, M. (2007). Media discourse: representation and interaction. Edinburg: Edinburg University Press.

Udasmoro, W. (2012). Pendidikan karakter dalam sastra anak. Yogyakarta: Sastra Prancis Universitas Gadjah Mada.

Udasmoro, W. (2013). Konstruksi identitas remaja dalam sastra anak. Yogyakarta: Sastra Prancis Universitas Gadjah Mada.

Van Dijk. (2006). Discourse, context and cognition. Discourse Studies, 8(1), 159-177.

Van Leeuwen, T. (2008). Discourse and practice: new tools for critical discourse analysis. Oxford: Oxford University Press.

Yunita, S., \& Udasmoro, W. (2015). Gender dan identitas dalam sastra di mata remaja. Masyarakat Kebudayaan dan Politik, 28(2), 94-105. 